\title{
Perception of Teachers on the Role of Staff Welfare Programmes in Selected Public Secondary Schools in Nakuru Sub-County, Kenya
}

\author{
Francisca A. Asino \\ Laikipia Univesity, Nyahururu, Kenya.
}

\begin{abstract}
Social welfare programmes (SWPs) have become common phenomena in Kenya today. They exist in various forms ranging from benevolent to revolving fund schemes. The aim of these programmes has been community development and to assist members in times of emergencies or financial hardships. Some SWPs have been very useful in taking care of members' interests and needs, others have turned into outfits that fleece the poor and others yet have collapsed due to poor management. This study focused on the perceptions of teachers towards the role of staff welfare programmes in public secondary schools in NakuruSub-County. The study adopted a descriptive survey design. The study population constituted all 533 teachers in Public secondary schools in NakuruSub-County from which a sample of 223 were drawn: 89 male and 134 females. The sampling procedure entailed stratified random sampling: male and female and purposive sampling. Data was collected using teachers' questionnaire that sought information on the respondent's personal data, the management of SWPs. The instruments were pre-tested to ascertain the reliability at 0.7 level of significance. The data collected was categorized into qualitative and quantitative data. Quantitative data was analysed through the use of descriptive statistics mainly frequencies, means and percentages while qualitative data was analysed through a descriptive interpretation of the respondent's views. The latest version of Statistical Package for Social Sciences computer programme (SPSS) 17.0 was used in data analysis. The result findings showed that teachers in Nakuru generally perceive the SWPs to be playing an important role in catering of their needs, even though they have different perceptions about specific aspects of management and services offered.
\end{abstract}

Keywords: Perception, Role, Management, Services

List of Abbreviations and Acronyms: CBOs: Community Based Organizations, COs: Charity Organisation Society, DSW: Doctor of Social Work, GSCC: Genera l Social Care Council, I.M.F: International Monetary Fund, K.N.U.T: Kenya National Union of Teachers, MA: Masters of Arts, MSc: Masters of Science, MSW: Masters of Social Work, NGOs: Non Governmental Organizations, Ph. D: Doctor of Philosophy, ROSCAS: Rotating, Saving and Credit Schemes, SWP: Staff Welfare Programmes, TSC: Teachers' Service Commission, U.S.A.: United States of America.

\section{INTRODUCTION}

Welfare refers to the health, comfort, happiness and general well-being of a person or group (World Book, 2001). In order to realize the above, many countries have come up with several social policies in a bid to alleviate poverty. But on the contrary it appears that the realization of such policies still remains a preserve of the developed countries (Wikipedia, 2008) Kenya, not being one of the developed countries, has limited resources for social welfare provision (Alila \& Mitula, 2003). In Kenya, poverty levels by the year 2005 were estimated at $56 \%$ of the population (RoK, 2005This has led to many people pooling their resources together to enable them cater for various needs. The result has been the formation of various social welfare programmes like Staff Welfare Programmes (SWPs), revolving fund schemes, benevolent fund schemes and many others. SWPs are therefore organizations within institutions that are supposed to cater for the general well-being of staff members. SWPs provide members with medical fees, money for funeral expenses, school fees, loans to cater for emergency needs, meals and many others, depending on particular institutions. The SWPs are in the long run expected to [promote staff cohesion, job performance and increase staff morale for better academic achievement of particular institutions. While some of the SWPs have been very useful in taking care of members' interests and needs, others have turned into outfits that fleece the teachers and yet others have collapsed due to poor management. 
These SWPs however have not addressed psychological effects that follow financial crisis like emotional stress, that if not dealt which could lead to more complicated psychological effects. With the inflation rates in Kenya rising to $17.76 \%$ by June, 2009 (RoK, 2009, Social Welfare Programmes have become common in public secondary schools where teachers are paid low salaries as compared to their civil service counterparts.

The financial constraint that may have created the need for teachers to come together through the formation of SWPs by pulling resources together with the intention of overcoming medical, housing, education and benevolent needs. SWPs have also been introduced in schools by the school administration to discourage teachers from asking for pay advance form their respective schools. The result is a variety of informal SWPs in various schools offering different services like loans to staff members, contributions for funeral expenses, footing medical bills, saving schemes and so on. The management of these welfare programmes also varies from one school to another. For example in most schools, membership to these welfare schemes is mandatory. These welfare schemes are at times managed by the school administrators who have immense powers over the teachers. This has created a need for a comprehensive study to explore the perceptions of teachers on the services and management of SWPs in public secondary schools in Nakuru Sub-County. Finding out the perception of teachers on these SWPs is important because as Santrock (2003) points out; perception enables us to categorize objects and people, for example, good or bad, strong or weak and active or passive. Blake and Sekuler (2006) further add that perception puts us into contact with the world we live in; it shapes our knowledge of that world, and knowledge is power. The way that the teachers view these programmes could influence their behaviours which could in turn influence their performance as individual teachers and even of the institutions they work in.

\section{Statement of the Problem}

One of the national goals of education in Kenya is equipping the youth with knowledge, skills and experience to play an effective role in national building among others. The attainment of these goals depends a lot on the teacher who is the implementer of the curriculum. Teachers contribute varying amounts of money for the operations of SWPs. The way the teachers view the management of the SWPs could greatly influence their participation and consequently the success or failure of these SWPs in addressing their needs

\section{THE PURPOSE OF THE STUDY}

The purpose of the study was to investigate teachers' perception towards the role of staff welfare programmes in selected Public Secondary Schools in Nakuru Sub-County.

\section{OBJeCtives OF THE STUdY}

i. To determine the teachers' perceptions towards the role of SWPs in meeting their needs in

Public Secondary Schools in Nakuru Sub-County.

ii. To examine the perceptions of teachers towards the management of SWPs in Public

Secondary Schools in Nakuru Sub-County.

\section{RESEARCH QUESTIONS}

i. What are the perceptions of teachers towards the role of SWPs in meeting their needs inPublic Secondary School in Nakuru Sub-County?

ii. What is the teachers' perception towards the management of SWP services and funds in Public Secondary Schools in Nakuru Sub-County?

\section{RESEARCh Methodology AND DESIGN}

\subsection{Research Design}

The study adopted a descriptive survey design which basically enquires into the state of affairs as it exists without questioning why it exists (Kombo\& Tromp, 2006). According to Mugenda and Mugenda (1999), a survey research seeks to obtain information that describes existing phenomena by asking individuals about their perceptions, attitudes, behaviour or values. The researcher has decided on the descriptive survey design because it is also an excellent vehicle for the measurement of characteristics of large populations. 


\subsection{Location of the Study}

The study was carried out in Nakuru Municipality in Nakuru District. Nakuru Municipality was chosen by the researcher purposively because it meets the criteria of having many secondary schools, diversity in culture and there is accessibility of the schools, and SWPs are operational in Public Secondary Schools, in the Municipality.

\subsection{Population of the Study}

The target population included all secondary school teachers in public schools within Nakuru municipality. According to 2008 records in Nakuru District Education office; there are 20 public secondary schools with 533 teachers; 212 male and 321 female. The accessible population was the same as the target population.

\subsection{Sampling Procedures and Sample Size}

A sample is a finite part of a statistical population whose properties are studied to gain information about the whole (Webster, 1985). In this study, stratified random sampling and purposive sampling was used. The teacher population of 533 was divided into two strata; that is 212 males and 321 females. The total sample size was determined by using Krejcie and Morgan (1970) formula as cited by Kathuri and Pals $(1993,54)$ as shown.

$$
\mathrm{S}=\frac{\mathrm{X}^{2} \mathrm{NP}(1-\mathrm{P})}{\mathrm{d}^{2}(\mathrm{~N}-1)+\mathrm{X}^{2} \mathrm{P}(1-\mathrm{P})}
$$

Where

$\mathrm{S}=$ Required Sample Size

$\mathrm{N}=$ the given population size

$\mathrm{P}=$ the population proportion of individuals that yield maximum possible sample size

(Assumed to be $(0.5)$

$\mathrm{d}=$ Degree of accuracy as reflected by amount of error that can be tolerated (taken as 0.05 )

$\mathrm{X}^{2}=$ Table value of chi-square for one degree of freedom taken as 3.841 for 0.95 confidence level

Using the above formula, the total sample size would be 223 .

Proportionate samples for each stratum were drawn to ensure equal representation of male (89) and (134) female teachers. Ten public secondary schools with established SWPs were purposively sampled for the study (Mugenda \& Mugenda, 1999). The final sample was drawn using simple random sampling from each of the ten schools.

\subsection{Instrumentation}

Data was collected through the administration of a questionnaire for teachers. The questionnaire sought to collect data on the respondents' personal information, management of SWPs in schools and the types of services offered by these SWPs. The questionnaire containtained rating scale questions whose main aim was to determine the perceptions of teachers towards the role of SWPs in their schools and factors influencing this perception: these items were rated on a five point Likert scale. Open-ended and contingency (filter) questions were also included in the questionnaire to provide greater insight into the respondent's feelings and recommendations.

\subsection{Validity}

This refers to the extent that a procedure or an instrument used in research is accurate, correct, true, meaningful and right (Kasomo, 2006). To enhance the validity of the instrument, the researcher reviewed the instrument in line with the objectives then three experts in the area under investigation were given the questionnaire to assess. Depending on their recommendations items that are unclear or ambiguous were either be rephrased or dropped. 


\subsection{Reliability}

This is a measure of the degree to which a research instrument yields consistent results or data after repeated trials (Mugenda \&Mugenda, 1999). To determine the reliability of the instrument, a pilot study was carried out to establish the clarity and comprehensibility of each item in the instrument. Three schools within Nakuru Municipality, which were not part of the sample but with similar characteristics were used. The researcher administered a single test to a sample of subjects. Then a score obtained in one item was correlated with scores obtained from other items in the instrument. The items in the instruments were standardized for validity using Cronbach's Alpha procedure. Cronbach's alpha will then be used to determine the correlation among the items. A coefficient of 0.7 will be acceptable as recommended by Fraenkel and Wallen (2000).

\subsection{Data Collection Procedures}

The researcher sought permission to collect data from the National Council for Science and Technology (NCST). The researcher then proceeded to the selected schools where permission was also gotten from the heads of the institutions. The researcher then explained to the teachers the purpose of the study and its importance. The researcher administered the questionnaire to the respondents and collected them soon after completion. The reason for doing this is to avoid external influence (Kathuri\& Pals, 1993). The researcher then went through all the questionnaires and coded them in readiness for data analysis.

\subsection{Data Analysis}

The data obtained was categorised into quantitative and qualitative data. Quantitative data was analysed through the use of descriptive statistics which entailed frequency counts, means and percentages. The qualitative data was analysed through the interpretation of the responses collected in reference to the objectives of the study (Mugenda \&Mugenda, 1999). The analysis was also done by the use of Statistical Package for Social Sciences (SPSS). The results obtained are presented using tables and graphs. Table 2 shows a summary of variables and data analysis approaches.

\section{RESUlTS AND DisCUSSION}

\section{Services offered by SWP to teachers in Nakuru Municipality}

An Investigation into the type of services offered by SWP revealed that benevolent services were the most popular with members indicating responses of $40 \%$ with a further $9.4 \%$ indicating that the contributions went to social functions. Other services cited included staff meals and medical advances that accounted for $3.1 \%$ and $2.7 \%$ respectively. Loaning services accounted for the least provided services at $0.4 \%$. The findings show that most SWPs offer benevolent services. This could be accounted for by the fact that these services have become very expensive and therefore members would require such assistance. The findings are presented in figure 4 .

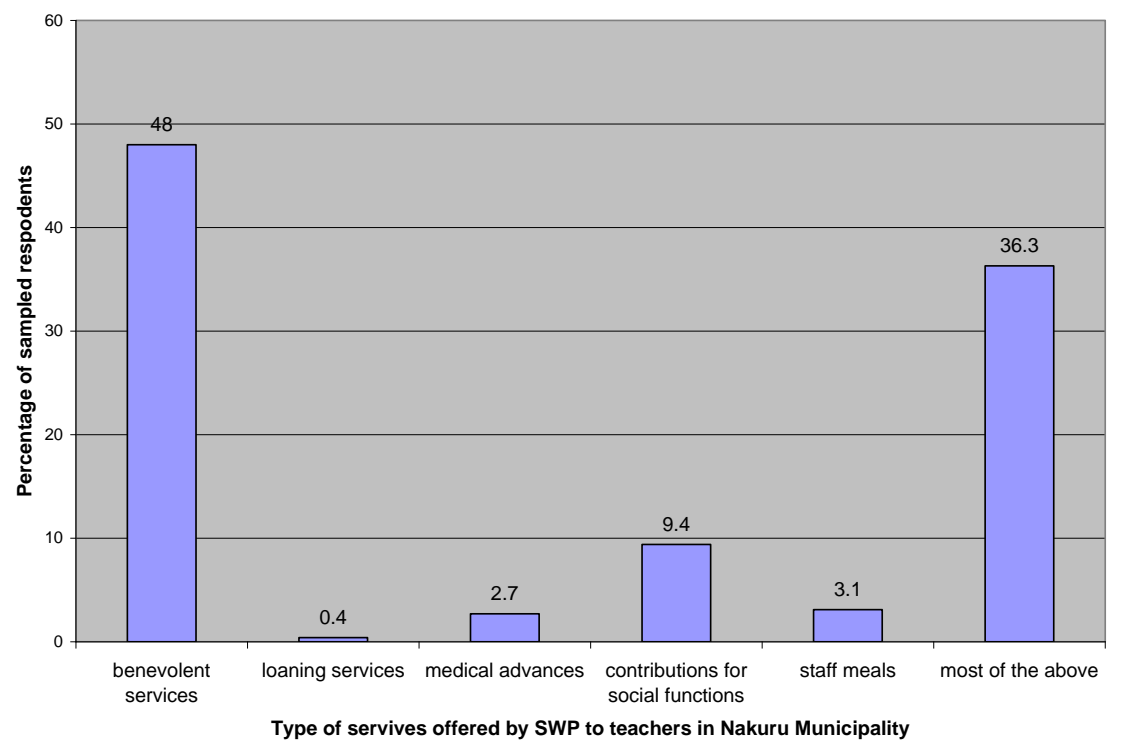

Figure1. Services are offered by SWP to teachers in Nakuru Municipality 
Perception of Teachers on the Role of Staff Welfare Programmes in Selected Public Secondary Schools in Nakuru Sub-County, Kenya

The perceptions of Teachers on the Role of SWP in Meeting Their Needs in Nakuru Municipality

An analysis of the teacher's perceptions on the role of SWP in meeting their needs revealed an overwhelming number of teachers having a positive perception with $82 \%$ affirming to this, while those that cited a negative perception accounted for $18 \%$ of the sample as illustrated in figure 1 . Further investigations indicated that a proportion of teachers agreed and strongly agreed with SWP in meeting their emergency needs accounting for $14.3 \%$ and $9.0 \%$ respectively. A further $20.6 \%$ were undecided on this performance with $37.2 \%$ disagreeing and another $18.8 \%$ strongly disagreeing.

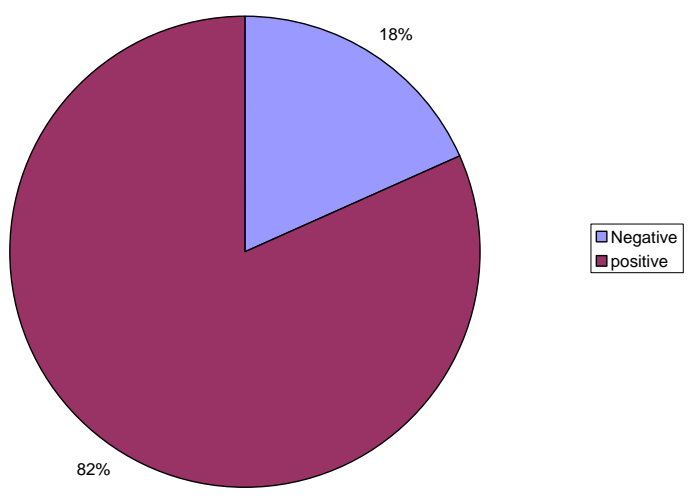

Figure2. Perception of teachers towards the Role of SWPs

The Teachers Perceptions on the Management of SWP Services and Funds in Nakuru SubCounty

The study sought to determine the teacher's perceptions on the quality of services provided by their SWP. This was viewed as an important question in determining their overall perceptions towards the management of their SWP. Finding indicated that a proportion of $43.9 \%$ teachers found the quality of service as being very important with a further $29.1 \%$ citing it is as important. Teachers that held a neutral position accounted for $6.6 \%$ with those viewing it as less important and not important $2.2 \%$ and $8.1 \%$ respectively. These results therefore suggest that the quality of services offered by SWPs is important to most teachers and therefore the improvement of these services would increase teacher participation in SWPs.

An analysis of the teacher's perceptions on the management of SWP services established a number of factors that played a critical role. These included the involvement of teachers in drafting of SWP by laws that had a large proportion of teachers agreeing and strongly agreeing accounting for $30.0 \%$ and $60 \%)$ respectively. Another perception that had relatively high responses agreeing and strongly agreeing was the prompt payment of welfare contribution accounting for $34 \%$ and $58.7 \%$. The findings showed that the teachers' perceptions on the management of SWPs were positive except for the election of officials that scored a low percentage. The SWPs therefore need to be very transparent (free and fair) in the election of their officials so that the members can be more confident about the management and participate effectively.

Table1. Perceptions towards Management of SWPs

\begin{tabular}{|l|c|c|c|c|c|c|}
\hline Statement & \multicolumn{2}{l|}{ Response (percent ) } & \\
\hline & SD & D & U & A & SA & TOTAL \\
\hline $\begin{array}{l}\text { involving members in drafting of } \\
\text { SWP by laws cab increase their } \\
\text { participation }\end{array}$ & 0.9 & 3.6 & 4.9 & 30.0 & 60.5 & $100.0(223)$ \\
\hline $\begin{array}{l}\text { prompt payment of welfare } \\
\text { contributions enhance service } \\
\text { delivery }\end{array}$ & 0.9 & 2.7 & 3.6 & 34.0 & 58.7 & $100.0(223)$ \\
\hline voluntary membership into SWP & 3.1 & 5.8 & 4.9 & 39.0 & 47.1 & $100.0(223)$ \\
\hline
\end{tabular}




\begin{tabular}{|l|c|c|c|c|c|c|}
\hline \hline could ensure commitment & & & & & & \\
\hline $\begin{array}{l}\text { my SWP services could be more } \\
\text { beneficial if supplemented by the } \\
\text { school administration }\end{array}$ & 2.7 & 9.9 & 9.4 & 36.3 & 41.7 & $100.0(223)$ \\
\hline $\begin{array}{l}\text { my welfare programme officials were } \\
\text { elected democratically }\end{array}$ & 6.7 & 12.1 & 22.9 & 31.8 & 26.5 & $100.0(223)$ \\
\hline
\end{tabular}

$\mathrm{N}=223$

\section{Factors influencing degree of participation in SWPs in Nakuru Municipality}

The study sought to determine the factors that influence teacher's participation towards the role of SWP. The teachers were presented with a set of questions were they were expected to respond to assess their position of factors deemed to affect SWPs. The factor that had the largest proportion of teachers indicting important and very important were quality of services and variety of services which had $29.1 \%$ respectively, $43.9 \%$ and $34.5 \%$ respectively. Another factor that registered high response rates in the category of important and very important were the aspect management style at $28.3 \%$ and $40.8 \%$. Religion registered a low response in this category at $4 \%$ respectively. Quality of services offered by SWPs and their management styles therefore need to be given priority by welfare officials as they are the two major factors that influence teacher participation in SWPs. The findings are presented in table 9 .

Table2. Factors influencing degree of participation in SWPS

\begin{tabular}{|l|l|l|l|l|l|l|}
\hline Factors & \multicolumn{3}{l|}{ Response (percent ) } & \\
\hline & NI & LI & N & I & VI & TOTAL \\
\hline Age & 33.6 & 12.1 & 19.7 & 18.8 & 15.7 & $100.0(223)$ \\
\hline Level of income & 32.7 & 8.5 & 10.8 & 22.0 & 26.0 & $100.0(223)$ \\
\hline Religion & 54.7 & 14.8 & 22.4 & 4.0 & 4.0 & $100.0(223)$ \\
\hline Management styles & 18.4 & 4.9 & 7.6 & 28.3 & 40.8 & $100.0(223)$ \\
\hline Compulsory membership & 33.6 & 13.9 & 15.2 & 23.3 & 13.9 & $100.0(223)$ \\
\hline Quality of services & 8.1 & 2.2 & 16.6 & 29.1 & 43.9 & $100.0(223)$ \\
\hline Variety of products & 12.6 & 13.5 & 10.3 & 29.1 & 34.5 & $100.0(223)$ \\
\hline
\end{tabular}

$\mathrm{N}=223$

\section{CONCLUSION}

The appeal of social welfare in societies have come alongin Kenya with emphasis being placed on the provision of support services for marginalized groups. Teachers as professionals have not been left out in institutionalizing welfare programmes in their work stations. The study indicates that in Nakuru Sub-County, the welfare programmes enjoy at the support of an overwhelming number of teachers especially in the provision of benevolent services. The SWPs however fall short of meeting the members' expectations in addressing their concerns during times of emergencies, democratic election of officials and variety of services offered.

\section{RECOMMENDATIONS}

a) There is a need for stakeholders to be involved in ensuring that stringent discipline measures are upheld through regular inspection of key accounting documents in an attempt to improve transparency and accountability.

b) There is a need for the SWPs to enhance benevolent services since they ranked as the most important in most welfare programmes sampled.

\section{REFERENCES}

[1] Alila, P. Mitulla, W.V.(2002) Enhancing Lobbying Capacity of Women Street Vendors: The challenges in Kenya Policy Environment Nairobi: IDS

[2] Baron, r. A. \&amp;Bryne D. (2004).Social Psychology with Research Navigator (10 th Edition). USA: Pearson Education, Inclination 
Perception of Teachers on the Role of Staff Welfare Programmes in Selected Public Secondary Schools in Nakuru Sub-County, Kenya

[3] Baugh, E.W. (1992). Introduction to Social and Community Services, London: The Macmillan

[4] Behemuka, J.M. \&amp;Brockington, J.L. (2004).East Africa in Transition: Images, Institutionand Identities. Nairobi, Kenya: University of Nairobi Press.

[5] Blake, R \&amp; Sekuler, S. (2006) Perception (5 th Edition). New York: McGraw -Hill

[6] Fadayomi, T,O (1991). The History of Social Development in Gambia, Ghana Nigeria, United Kingdom: ACARTSOD

[7] Finsterbusch, K. (2004). 12 th Edition Taking sides: Clashing Views on Controversial Social Issues. U.S.A: McGraw -Hill/Dushkin

[8] Hill, M. (1988) Understanding Social Policy. United Kingdom: Blackwell publishers.

[9] Kathuri, N.J and Pals, A.D. (1993).Introduction to Educational Research. Egerton: Educational Media Centre. Kenya.

[10] Kenneth, P.(2001). Comparative Social Policy: Theory and Research. Great Britain: Open University Press.

[11] Kowalski, R \&amp; Western, D. (2005).Psychology (4 th Edition) U.S.A: John Wley \& amp; Sons

[12] Inclination

[13] Mugenda, M.O. \&amp;Mugenda, A.G (1999).Research Methods: Quantitative and Qualitative Approaches. Nairobi: Act Press

[14] Mutie, E.K.\&amp;Ndambuki, P. (1999). Guidance and Counselling for Schools and Colleges. Kenya: Oxford University Press

[15] Onyuma, S.O. Birach, E.R. \&amp;Owuor, G. (2001).Fighting Ignorance in Kenya: Role of Business on Education, Unpublished Paper Presented at the 2 nd ATW Conference at Egerton University, March 2001

[16] Osei-Hwedie, K. \&amp; Bar-on, (1999).Sub-Saharan Africa: Community-Driven Social Policies. London: Earthscan.

[17] Oyugi, E. (n.d) html document: The Elusive Face of Kenya's social and Welfare Service. Retrieved august 05,2008

[18] Rok (2005) UNDP Development Cooperation Report

[19] RoK. (2006). Economic Survey: Central Bureau of Statistics: Ministry of Planning \&amp; National Development. Nairobi: Government Printer.

[20] RoK.(2009) Inflation Rates. Retrieved July 10, 2009 from http://.centralbank.go.ke

[21] Santrok, J.W. (2003) Psychology: Essentials (2 nd Edition). New York: McGraw-Hill Higher Education.

[22] Santrock, J.W. (2005). A Tropical Approach to life -span development (2 nd Edition) McGraw Hill Higher Education

[23] Semboja, J.\&amp; Ole Thekilsden, (2001). Service Provision Under Stress in East Africa. Nairobi: EAEP

[24] Suppes, M.A. (2000) The Social Work Experience: An Introduction to the Social Work and social Welfare. U.S.A McGraw Hill Higher Education.

[25] The World Book Encyclopedia (2001) U.S.A World Book Inclination

[26] Weiten, W. (2006).Psychology: University of Montana. Fall 2006 Edition with Syllabus. U.S.A Thomson Wadswroth.

[27] Wikipedia, (2008) The Free Encyclopedia. Retrieved August 03, 2008, from http:en.wikipedia.org/

[28] Yeo, A. \&amp; Lovell, T. (2002).Sociology and Social Policy for the Early Years. London: Hodderd \&amp; Stoughton. 